\title{
FLOOD RISK ASSESSMENT AND MANAGEMENT IN SLOVAK REPUBLIC
}

\section{Martina Zeleňáková}

Technical University of Kosice, Civil Engineering Faculty, Institute of Environmental Engineering, Associate Professor

\begin{abstract}
Recent history has shown that extreme hydrological events as flood and droughts can create additional stress on water supplies essential for human and ecosystem health. Floods have caused immense economic and social losses, mainly as a result of unplanned urbanization, uncontrolled population density and not strictly inspected construction by authorities. The purpose of Directive 2007/60/EC is to establish a framework for the assessment and management of flood risks, aiming at the reduction of the adverse consequences for human health, the environment, cultural heritage and economic activity associated with floods in the Community. The main aim of this paper is to present way of flood risk assessment and management in conditions of Slovak republic.
\end{abstract}

Key words: flood; flood risk assessment; eastern Slovakia

\section{PROCJENA RIZIKA OD POLAVE I UPRAVLJANJE RIZICIMA OD POPLAVE U SLOVAČKOJ}

Sažetak: Nedavna povijest je pokazala da ekstremni hidrološki događaji kao poplava i suša, naglašavaju potrebu za zalihama vode neophodne ljudskom zdravlju i ekosustavu. Poplave su uzrokovale ogromne ekonomske i socijalne gubitke, uglavnom kao rezultat neplanirane urbanizacije, nekontrolirane naseljenosti, uz izostanak strožeg nadzora radova tijekom gradnje. Svrha Direktive 2007/60/EC je uspostaviti okvir za procjenu i upravljanje rizicima od poplava radi smanjivanja štetnih posljedica za zdravlje ljudi, okoliš, kulturnu baštinu i gospodarsku aktivnost u Europskoj zajednici. Glavni je cilj ovoga rada prikazati način procjene rizika od poplava i upravljanje rizicima od poplava u Slovačkoj.

Ključne riječi: poplava; procjena rizika od poplave; istočna Slovačka 


\section{Introduction}

Flood risk means the combination of the probability of a flood event and of the potential adverse consequences for human health, the environment, cultural heritage and economic activity associated with a flood event 2007/60/EC [1].

A flood is a hydrological event characterized by high discharges and/or water levels that can lead to inundation of land adjacent to streams, rivers, lakes, wetlands and other water bodies [2]. Usually we talk about streams and channels being unable to convey the amount of water that has been generated through the runoff process, and consequently there is an overspill of water. However, floods may also be generated by the inability of water to escape downstream due to high water levels in receiving channels. Flood events are caused and/or exacerbated by intense of long-lasting rainfall, snowmelt, and failure of a dam or embankment system, earthquakes, landslides, ice jams, high tides, storm surges and by human activities, including the operation of flood control systems [3].

With global climate change and the expected increase in extreme climatic events, the possibility of severe dry spells and heavy rainstorms is also likely to further exacerbate the situation, especially in the most flood vulnerable areas. There is therefore an urgent need to introduce mitigation measures to ensure that these areas are protected so that erosion and flooding is minimized.

In past ten years it came to more than hundreds large floods in Europe including catastrophic floods on Danube and Labe Rivers in 2002. Those floods implicated the loss of human lives, evacuation of inhabitants and economic losses in milliards EUR. Most countries in the world experience floods and flooding, even if such events are rare in some arid climates. As such they bring the risk of loss of life. Unlike other catastrophic natural events such as earthquakes, landslides, volcanic eruptions, avalanches, floods are much more widely distributed, and therefore there is a huge experience around the world of learning how to live with floods.

Flood risk assessment is an assessment of the risk of flooding, particularly in relation to residential, commercial and industrial land use. Flood risk assessment evaluates the potential adverse impacts that floods have on humans and the environment. Flood risk management is a process which comprises pre-flood prevention, risk mitigation measures and preparedness, backed up by flood management actions during and after an event. Flood risk management deals with the societal task of analyzing, assessing and reducing flood risks considering all relevant physical, environmental and societal processes [1].

Floods have consequences for a wide range of structural, economic, social and environmental factors. We may be interested in the physics of flood generation and propagation, but the consequences of floods are what provide the primary incentive to study such phenomena. The intermittent, infrequent occurrence of major floods means that they are perceived as threats to society, and therefore have associated with them a number of risks. A comprehensive flood risk assessment is, however, extremely difficult. The paper deals with flood risk assessment and management in Slovakia, especially in its eastern part.

\section{Study area}

Slovakia belongs to Danube River Basin (Figure 1). Danube river basin is the second largest in Europe, has an area of $801463 \mathrm{~km}^{2}$ and covers an area of 18 states. River Danube is $2780 \mathrm{~km}$ long and flows roughly west to east, with a sliding path south to a long stretch between the Slovak Republic and Serbia. The largest sub-basin in the Danube basin $\left(157,186 \mathrm{~km}^{2}\right)$ is Tisza River Basin. River Tisza can be divided into three main parts:

- A mountainous area of the upper Tisza in Ukraine and Romania;

- Central Tisza in Hungary, which receives major tributaries: Bodrog and Slaná that collecting water from the Carpathians, Slovakia and Ukraine, as well as Samos, Kris river system and the river Mures, which diverts water from Transylvania in Romania, and

- Lower Tisza degrading Hungarian-Serbian border, where it directly translates into Begej and other tributaries indirectly through a system of channels of the Danube - Tisa - Danube. 


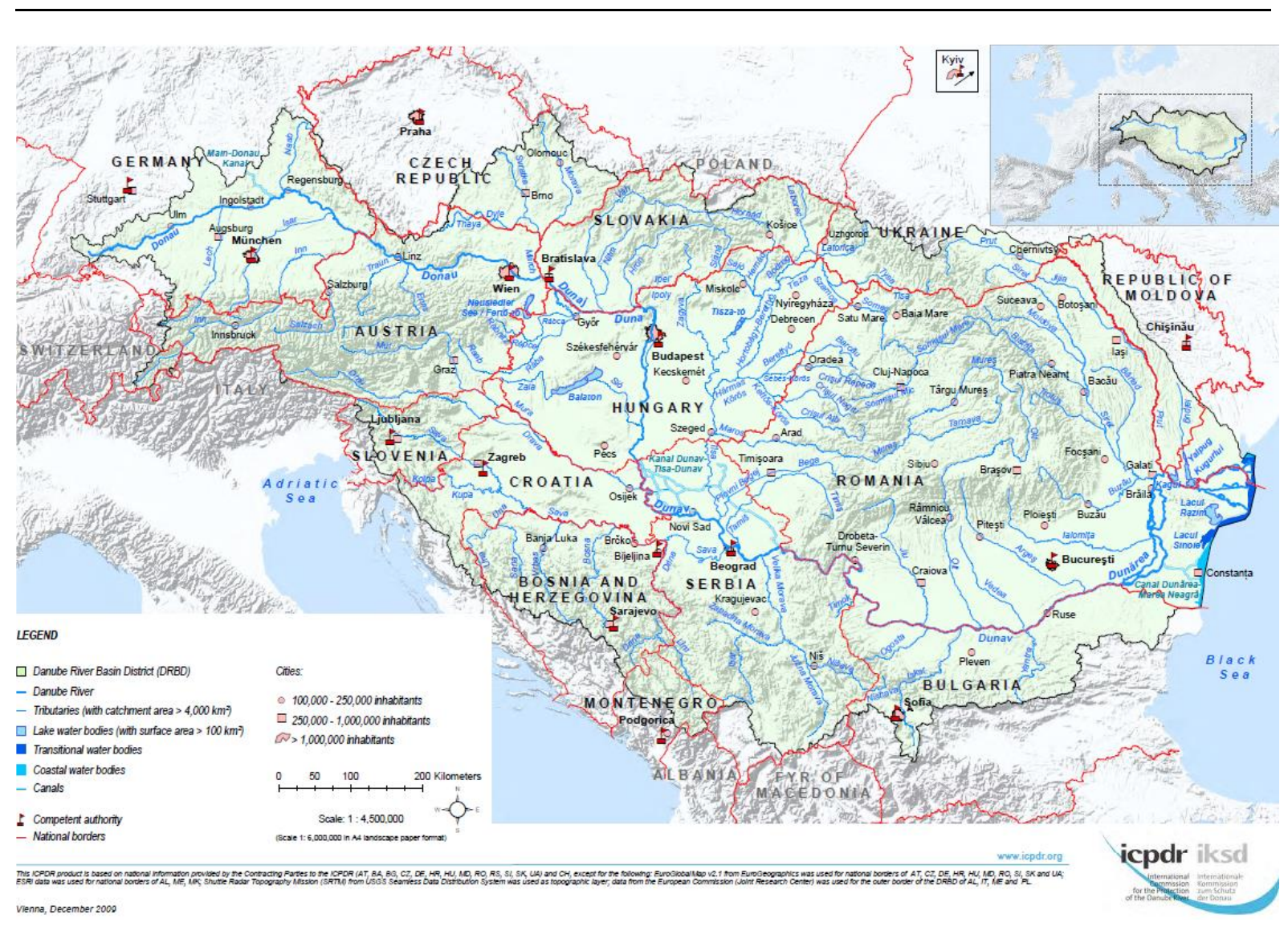

Figure 1 - Danube river basin [4]

Tisza is also the longest tributary of the Danube is $966 \mathrm{~km}$ long. On the occasions when it was gradually built up the largest flood protection system in Europe, canalization, construction of flood protection embankments and low walls, drain systems, pumping stations and are designed to complement other retention tank.

Flood damages that arose on watercourses and hydraulic structures on the territory of the Slovak Republic, according to Slovak Water Management Enterprise, s.c. have been huge. It is obvious that most affected is just eastern Slovakia, where is the most complex situation in Bodrog river basin, which include Topla, Ondava, Torysa, Laborec river basins and Hornád river basin.

Bodrog river is $15,2 \mathrm{~km}$ long at Slovak republic but its basin area is $7272 \mathrm{~km}^{2}$ (Figure 2). Territory of Bodrog basin is located in two orographic subassemblies, which are the Carpathians and Pannonian Basin. The morphological type of the relief is predominantly plane in the southern part, hilly in the northern part. Bodrog river valley has varied climatic conditions. Precipitations are highly differentiated. The highest annual totals are mainly at east border mountains and Vihorlat where rainfall totals is about of $1.000 \mathrm{~mm}$. Decrease of total precipitation is quite intense direct to the south - annual totals fall to below $800 \mathrm{~mm}$. Lowland part of the Michalovce - Lastomír and Medzibodrožie belong to among the driest in the eastern region (550 $\mathrm{mm}$ rainfall per year). Hydrographic conditions of Bodrog and Danube river basins and its comparison are presented in table 1.

Table 1 - Hydrology bilance in the partial basins (period 1961 - 2000)

\begin{tabular}{|l|l||c|c|c|}
\hline \multirow{2}{*}{ Territory } & Area & Rainfall $(\mathrm{P})$ & Runoff $(0)$ & $\mathrm{P}-\mathrm{O}$ \\
\cline { 2 - 5 } & {$\left[\mathrm{km}^{2}\right]$} & {$[\mathrm{mm}]$} & {$[\mathrm{mm}]$} & {$[\mathrm{mm}]$} \\
\hline Partial basin of Bodrog in Slovakia & 7272 & 718 & 235 & 483 \\
\hline Slovak part of Danube basin & 45658 & 743 & 236 & 506 \\
\hline
\end{tabular}


Under the influence of long-lasting and intensive precipitations numerous flood waves, which are not fully controllable by manipulations on hydraulic structures, arise. The water levels in many profiles on watercourses reached historical maximums [5].

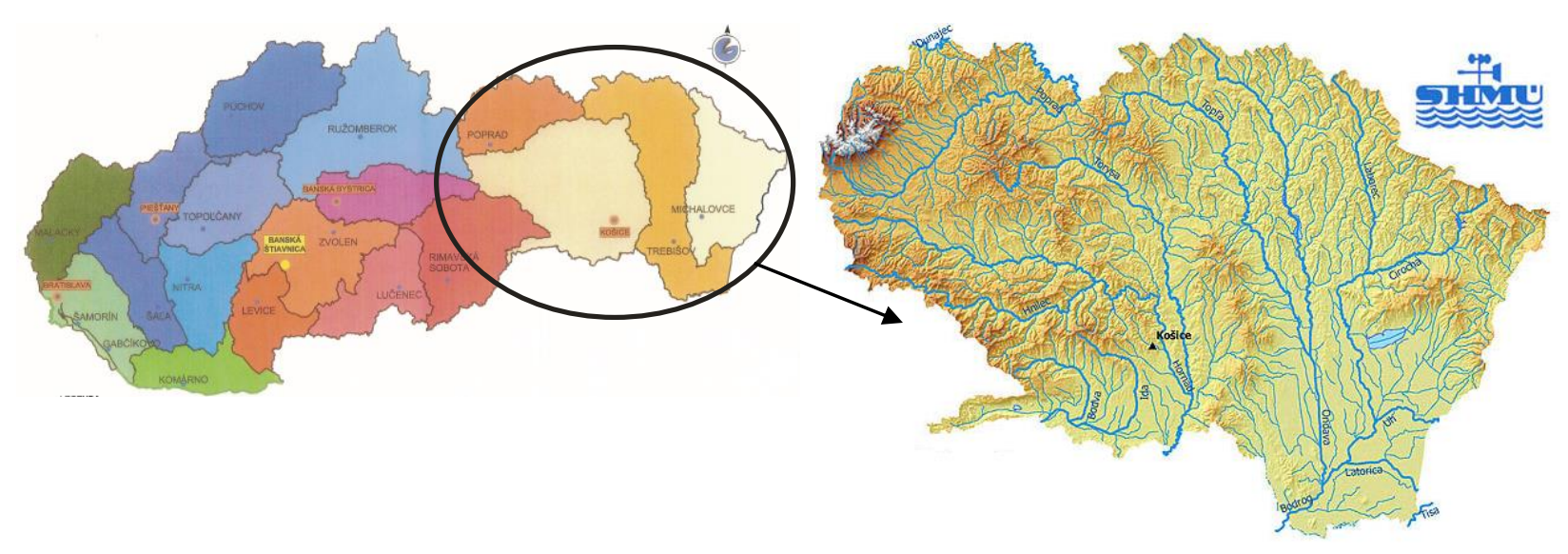

Figure 2 - Bodrog and Hornád river basin

(source: Slovak Water Management Enterprise, s.c. Slovak Hydrometeorological Institute [7])

The morphological type of terrain in Hornád river valley is dominated by rolling hills, highlands and lower highlands. The southern sub-basin is part of a plane and Slovak Kras and is formed by moderately higher rugged highlands. Geological structure of the territory determines the hydro-geological conditions of the basin. We meet here with all the geological formations from palaeozoic to quaternary. Sub-basin of the Hornád valley can be assigned to areas with a strong predominance of impervious, respectively poorly permeable rocks with moderate to low permeability. Well-drained rocks with high permeability are only in Spiš and Gemer areas and in Slovak Kras near Košice.

\section{Flood risk assessment}

The European Commission issued a Communication about flood risk management in 2004. This initiative was followed by the adoption by the European parliament and the council of Directive 2007/60/EC on the Assessment and Management of Flood Risks on 23 October 2007 [1].

According to 2007/60/EC EU Member States shall complete the preliminary flood risk assessment by 22 December 2011. Based on available or readily derivable information, such as records and studies on long term developments, in particular impacts of climate change on the occurrence of floods, a preliminary flood risk assessment shall be undertaken to provide an assessment of potential risks. The assessment shall include at least the following:

- maps of the river basin district at the appropriate scale including the borders of the river basins, subbasins showing topography and land use;

- a description of the floods which have occurred in the past and which had significant adverse impacts and for which the likelihood of similar future events is still relevant, including their flood extent and conveyance routes and an assessment of the adverse impacts they have entailed;

- a description of the significant floods which have occurred in the past, where significant adverse consequences of similar future events might be envisaged;

- an assessment of the potential adverse consequences of future floods, taking into account as far as possible issues such as the topography, the position of watercourses and their general hydrological and geo-morphological characteristics, including floodplains as natural retention areas, the effectiveness of existing man-made flood defense infrastructures, the position of populated areas, areas of economic activity and long-term developments including impacts of climate change on the occurrence of floods. 
The preliminary flood risk assessment will be used to identify areas which need to be considered in more detail through mapping and potentially the preparation of flood risk management plans [1]. In order to assess flood risk it is necessary to identify both the probability and consequences of flooding.

The preliminary flood risk assessment is based on the occurrence of floods during the year in the area of Slovakia. Figure 3 presents that the worst flood situation is in the eastern part of Slovakia.

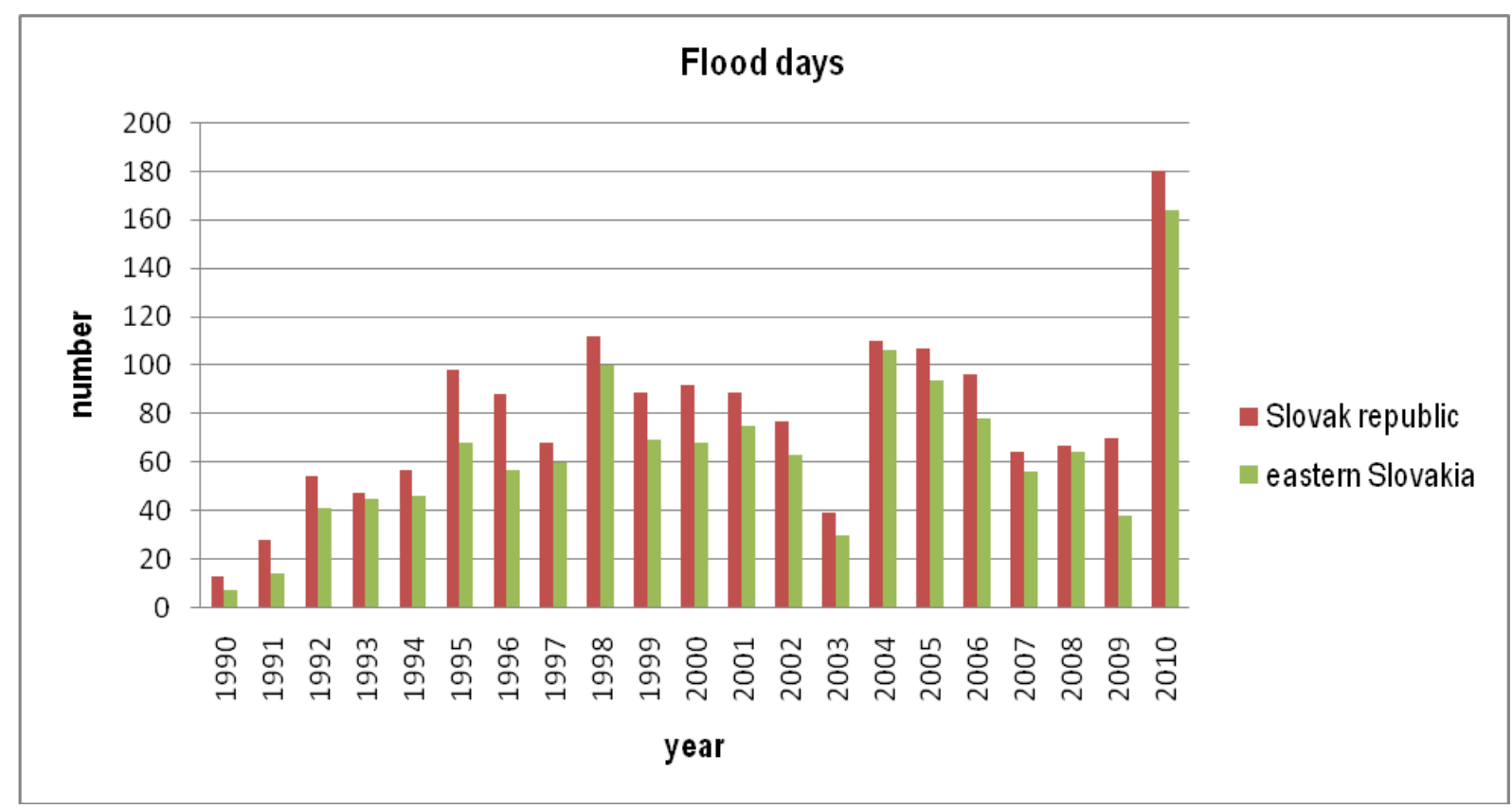

Figure 3 - Number of flood days during period 1990 - 2010

Flood hazard maps and flood risk maps EU Member States shall prepare by 22 December 2013. Flood risk maps shall show the potential adverse consequences associated with flood scenarios. Flood hazard maps shall cover the geographical areas which could be flooded according to the following scenarios:

- floods with a low probability, or extreme event scenarios;

- floods with a medium probability (likely return period $\geq 100$ years);

- floods with a high probability, where appropriate.

For each scenario the following elements shall be shown:

- the flood extent;

- water depths or water level, as appropriate;

- where appropriate, the flow velocity or the relevant water flow.

Flood risk maps shall show the potential adverse consequences associated with flood scenarios and expressed in terms of the following:

- the indicative number of inhabitants potentially affected;

- type of economic activity of the area potentially affected;

- installations concerning integrated pollution prevention and control which might cause accidental pollution in case of flooding and potentially affected protected areas;

- other useful information such as the indication of areas where floods with a high content of transported sediments and debris floods can occur and information on other significant sources of pollution.

The Exchange Circle on Flood Mapping (EXCIMAP) has made an inventory of flood mapping practices in Europe. This inventory has resulted in a "Handbook on Good Practices for flood mapping in Europe" and an „Atlas of Flood maps containing examples from 19 European countries, Japan and USA“ [6].

In the Slovakia Water Research Institute in cooperation with Slovak Water Management Enterprise, Slovak Hydrometeorological Institute and Environmental Institutes have prepared the map (Figure 4) that will be the basis for flood risk mapping. 


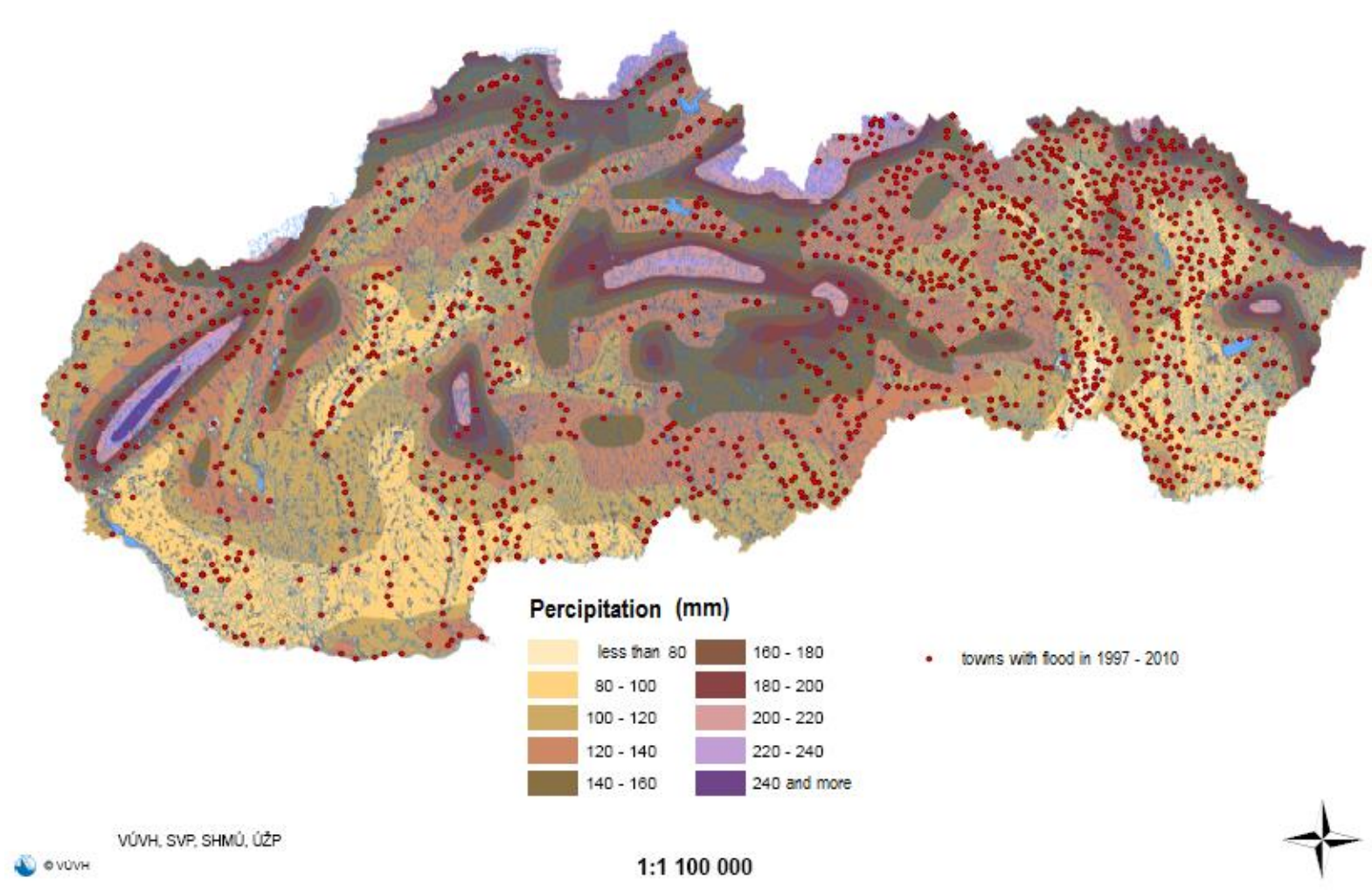

Figure 4 - Map of potential flood risk in Slovak republic

(source: Slovakia Water Research Institute [8])

On the basis of the maps Member States shall establish flood risk management plans by 22 December 2015. Flood risk management plans shall take into account relevant aspects such as costs and benefits, flood extent and flood conveyance routes and areas which have the potential to retain flood water, such as natural floodplains, the environmental objectives of Directive 2000/60/EC, soil and water management, spatial planning, land use, nature conservation, navigation and port infrastructure. The purpose of the flood risk management plans is to identify means of reducing the impacts of flooding.

\section{Flood risk management}

A comprehensive risk management approach consists of a combination of prevention, preparation, response and recovery. The main recommendations for flood risk assessment and management (modified according to Simonovic [9]) are:

- to fully exploit basic and advanced information technologies to improve environmental representation, flood characterization and prediction, and to foster intersectoral communication and collaboration;

- $\quad$ to continue introduction of flood risk and impact assessment with any new development proposal;

- to continue advancement of integrated floodplain management principles and practices, including a more fully balanced approach of structural and nonstructural flood protection measures;

- to proceed with the development of variable procedures to more effectively manage the flood risk within various sectors of society;

- to enhance awareness of local flood management capacities and the need for affected groups and individuals to assume their share of the risk;

- to continue advancement of strategies to involve a broader range of groups and individuals in decisionmaking processes based on common, basin-wide visions; and

- to continue exchange of information related to flood management through regional and international initiatives and meetings. 
Preventive measures reduce the probability of flooding of assets by spatial planning and construction and maintenance of flood protection works, like embankments [10]. Preparation, response and recovery reduce the consequences when preventive measures fail. Preparation includes emergency planning and early warning. Response includes disaster management, crisis communication and evacuation. Recovery includes rebuilding of damaged assets and payment for financial losses by insurance companies.

\section{Conclusion}

The cause of flooding is extremely heavy rains or rapid melting of snow combined with a significantly reduced ability to detain storm water in areas (mainly because of damage of the country - e.g. drained wetlands, farmland, and drainage). The primary impulses of torrential floods are usually extremely intense precipitation which falls in the short term for relatively small and sharply defined area (several $\mathrm{km}^{2}$ ). Despite the relatively high density of precipitation stations in Slovakia (700) is almost certain that through this network measurements can be recorded only about a third of extremely high short-term totals.

The total catchment's hydrological response to intense rainfall is determined by its natural environment, a whole complex of characteristics of the river basin. The intensity and frequency of precipitation events, which are capable of extreme runoff and subsequent flooding in Slovakia during recent years has increased significantly. End of the second and the beginning of the third millennium has brought to the region of the eastern Slovakia in the short term many large floods with devastating consequences. The damage caused by floods is a common effect of two independent mechanisms natural conditions and maybe more - the human activities in the basin.

People must learn to live with floods in the future. The value of the property threatening flooding is increasing. Therefore, attention must focus on the whole society to prevent and protect itself from big water to reduce or damage minimized. The appropriate flood risk mitigation investment, and the redirection of resources into flood disaster prevention, offers significant economic benefits, as well as reduction in loss of life and property, improvements in welfare and social stability. Flood risk reduction also according to Directive 2007/60/EC is an integral part of river basin management and which aims to maximize the resultant economic and social welfare in an equitable manner without compromising the sustainability of vital systems.

The Centre was supported by the Slovak Research and Development Agency under the contract No. SUSPP-0007-09.

\section{References}

[1] Directive on the assessment and management of flood risks (2007/60/EC). Official J, L288, pp. 27-34. Brussels: The European Parliament and the Council of the European Union, 2007.

[2] Key Elements of the EU Directive. Available at: http://www.floodsite.net/html/eu_directive_keyelements.htm

[3] Šlezingr, M. (2009): Reasons of the revitalization of watercourses. In: Selected Scientific Papers. Journal of Civil Engineering. Vol.4, Issue 1, p.69-80.

[4] Danube river basin. Available at: http://www.icpdr.org/icpdr-pages/drbmp_maps_2009.htm

[5] Floods. Slovak Water Management Enterprise, s.e., http://www.svp.sk/svp/default.asp?id=10\&mnu=10

[6] Handbook on good practices for flood mapping in Europe Handbook on good practices for flood mapping in Europe European exchange circle on flood mapping (EXCIIMAP), 2007. Available at: http://ec.europa.eu/environment/water/flood_risk/flood_atlas/pdf/handbook_goodpractice.pdf

[7] Bodrog and Hornád river basin. Slovak Water Management Enterprise, s.c., Slovak Hydrometeorological Institute.

[8] Map of potential flood risk in Slovak republic. (2011): Slovakia Water Research Institute.

[9] Simonovic, S. P. (2009): Managing flood risk, reliability and vulnerability. J Flood Risk Manage, 2, pp. 230 231.

[10] Zeleňáková, M. (2009): Flood risk assessment. Thesis. Košice: Technical University of Košice, Faculty of Civil Engineering. 